\title{
Fertility Status of Organic Soils in Puerto Rico ${ }^{1}$
}

\author{
Juliain Roldán ${ }^{2}$ \\ INTRODUCTION
}

FORMATION OF ORGANIC SOILS

The nature of the formation of organic soils is quite different from that of mineral soils. These very peculiar soils are formed when partly decomposed plant material accumulates in water or in water-saturated soils. The exclusion of air is a factor of outstanding importance in the process. The reducing conditions encountered favor anaerobic micro-organisms. These are capable of breaking down only a few of the organic complexes in plant materials, leaving the remaining plant constituents to accumulate in the form of relatively unavailable carbon and nitrogen compounds of peat $(3)^{3}$. Under anaerobic conditions, sugars, amino acids, starches, certain hemicelluloses, and proteins are rapidly decomposed. Celluloses, oils, certain fats, and certain hemicelluloses are decomposed more slowly. The rapidity of decomposition is controlled to some extent by the amount of available nitrogen and minerals (29).

The major processes of peat formation are paludification of dry land and filling processes (29). These major soil-making processes may lead to either impoverished or enriched peat soils. Accordingly, peat soils have been classified as oligotrophic, eutrophic, or mesotrophic, meaning rich, poor, or intermediate in terms of lime and mineral-element content. These soils are further distinguished by a sequence of layers. The chemical composition of a definite layer depends primarily upon four factors (31):

1. Watershed.

2. Nature of the plant remains which have contributed to the formation of the layer.

3. Environmental conditions that predominated dưring the time of the formation of the layer.

1 Part of a thesis submitted to the Faculty of the Graduate School of Cornell University, Ithaca, N. Y., in partial fulfillment of the requirements for the degree of Master of Science.

${ }^{2}$ Assistant Chemist, Agricultural Experiment Station, University of Puerto Rico, Río Piedras, P. R. The author wishes to express his sincere gratitude to Jeffery $\mathbf{E}$. Dawson for his guidance throughout the conduct of this investigation; to Douglas J. Isalhwell for his help in allowing the soil tests to be performed in the Soil Fertility Laboratory, and for serving as a member of his committee; and to Gilberto Acevedo and Raúl Pérez Escolar for taking the soil samples.

${ }^{3}$ Italic numbers in parentheses refer to Literature Cited, pp. 266-7. 
4. Extent and nature of the processes of decomposition of the plant residues in the particular layer.

These layers show either progressive or regressive development. Progressive development is shown by bogs that have always developed from a wet toward a drier state. Regressive development is illustrated by a change from a relatively dry to a wetter state (4).

Whenever the degree of decomposition of the plant material is such that it cannot be identified, the soil is called a muck. All organic soil-surface layers eventually reach this stage of decomposition. Decomposition of peat into muck can be ascertained by making a paste with the soil and sodium pyrophosphate. In pyrophosphate the humic acids go into solution and in doing so indicate that decomposition is under way. This type of decomposition is characteristic of partly drained organic soils.

Some plant communities forming organic soils include plants capable of precipitating calcium, e.g., submerged plants. This may lead to the formation of a layer of calcium carbonate mixed with organic matter, marl. Besides this layer, profiles may also include layers of sedimentary peat, e.g., gyttja, fibrous peat, and fibrous moss peat.

There are different plant associations that give rise to different peats. Duckweed, pondweed, green algae, and blue-green algae form sedimentary peat by supra-aquatic filling. Reeds, sedges, and cattails lead to fibrous peat formation by infra-aquatic filling. Sphagnum moss, labrador tea, tamarack, and black spruce form fibrous peat.

The rate of peat formation has been evaluated from pollen-grain curves and radio-carbon data. The values found are: $0.0021 \pm 0.0006$ and $0.0021 \pm$ $0.0013 \mathrm{foot} / \mathrm{year}$, respectively.

\section{SUBSIDENCE}

Whenever organic soils are drained, a reduction in depth of the soil will be observed; this is termed "subsidence." Lowering of the water table makes possible a better aeration of the soil and, as a result, the rate of decomposition is increased.

Laboratory studies indicate that the rate of decomposition depends on the type of peat, which, in turn, is determined by the climatological conditions under which the peat was formed (14). The greatest decomposition of the soil will take place with temperatures over $75^{\circ} \mathrm{F}$. and with moisture contents between 50 and 75 percent by volume for a soil containing 90 percent of water at saturation (11).

It has been observed that when a virgin peat or muck is brought into use, the rate of subsidence is rapid at first, but decreases with time. The rate appears to be proportional to the depth to water table. Data published by the University of Florida Agricultural Experiment Station in relation to 
the subsidence rate in the Everglades show that the relation between the depth to water table and subsidence is as follows (10):

$\begin{array}{cc}\begin{array}{c}\text { Average depth of water lable } \\ (\text { F eet })\end{array} & \begin{array}{c}\text { A verage annual subsidence } \\ (\text { Feet/year) }\end{array} \\ 1.0 & 0.03 \\ 1.5 & .06 \\ 2.0 & .08 \\ 2.5 & .11 \\ 3.0 & .14\end{array}$

Subsidence may occur as a result of compaction and shrinkage. Shrinkage is especially noticeable after the land is first drained. When planning the reclamation of peat lands the rate of subsidence should be considered since it will limit the period of years during which the land may be cultivated profitably. Investigational work in the Everglades carried on by Neller (15) has shown that maintenance of the water table at as high a level as possible provides the only means of conserving the soil from subsidence.

WATER TABLE

The depth to the water table in an organic soil is important. As has already been pointed out, subsidence is proportional to depth to the water table and, to minimize subsidence, the water table should be maintained as high as other considerations will permit. For crop production the water table should be high enough to supply sufficient water for optimum growth, and it should be low enough to prevent crop growth from being retarded by poor soil drainage. The ratio of water-table rise to rainfall is approximately 6 in organic soils ${ }^{4}$. The permeability of some organic soil layers to water is relatively low. The depth to the water table should accommodate all regularly occurring rains without crop damage due to poor drainage. Stoutmire (24) found that with a water table 3.5 feet below surface, plants suffered from lack of moisture. At 1 foot plants suffered from too much moisture, and at 2 feet he found the best environment.

The importance of controlling depth to the water table has been shown by Ellis and Morris (6) when they found that there was a negative correlation between a test for ferrous iron and the yield of crops. By means of this test they were able to determine the regions of the soil in which aeration took place.

\section{CHEMICAL PROPERTIES OF ORGANIC SOILS}

Many other factors besides subsidence and water table have to be taken into consideration whenever muck soils are put into production. Unlike mineral soils, where the parent material determines fertility status, organic

- Personal communication given by Dr. J. E. Dawson to the author. 
soils depend on the bog-plant associations from which they were derived for their fertility status. Anyway, both organic and mineral soils can exhibit deficiency or toxicity of elements. It is of general knowledge that most virgin peat soils are of low fertility level, particularly with respect to phosphorus and potassium.

Neller (16) has pointed out that the protein in molasses from sugarcane grown on Everglades organic soils is higher than when the cane is grown on mineral soils. This makes the molasses much more valuable for feed.

Staker (22), working on some New York peat soils, considered that the presence of exchangeable zinc may be a cause of toxicity in these soils. Moreover, he found that a wide zinc-to-sulfide ratio was associated with poor growth of crops. A narrow ratio was correlated with fair to good growth. As zinc sulfide is insoluble in water he concluded that most of the toxicity prevalent in the soils under study was caused by other forms of zinc. Other studies at the Belle Glades Experiment Station (26) have shown that, on alkaline organic soils, considerable quantities of zinc are held as the humate and carbonate.

Neller (17) studying low- and high-lime peats, found that in high-lime peats the conditions were optimum for nitrification and that the conversion of the nitrogenous material of the peat was rapid. There was no indication that pasture grass, corn, or sugarcane would respond to a nitrogenous fertilizer, except for brief periods following a succession of heavy rains.

In an attempt to identify lime-deficient peats Nygard (18) reached the conclusion that acidity values without lime determinations can be utilized to recognize many peat soils not deficient in lime. He further found that lime-deficient peats from uncultivated bogs contained less than 0.63 percent of $\mathrm{CaO}$ in the dry peat and 0.74 percent in the ash-free dry matter. As a further clue he emphasized that Azotobacter is more numerous in limesufficient peats.

Allaway (1) investigated the availability of replaceable calcium from different types of colloids as affected by degree of calcium saturation. Of the five colloids investigated, peat was the one that gave the highest replaceability.

Copper-deficiency symptoms have been observed in crops grown on peat soils. Sugarcane growing on saw-grass peat soils has been observed with marked copper-deficiency symptoms. A tremendous response has been observed when the soil is treated with copper salts (27). Forsee, et al. (7), in an experiment using copper oxide as a source of copper for plants, indicated that finely ground copper oxide is as efficient as copper sulfate. Harmer (9), working with several crops on organic soils, showed that a considerable response to copper is obtained if the soil $\mathrm{pH}$ is around 6.0 or below. The lower the $\mathrm{pH}$ the greater the number of crops which are likely 
to show a response. It has been observed by the author that the amount of response to copper shown by a given crop may vary from year to year and from one part of a growing season to another. Generally more response was obtained in a hot dry period than in a cool wet period.

Lucas (12), studying minor-element deficiencies and responses in plant growth on organic soils, suggested that copper is less available in limed mucks than in slightly acid mucks. During his studies he found that the addition of copper reduced slightly both the zinc and manganese absorption by plants. It seemed to him that plants deficient in copper absorb excessive amounts of manganese because of a physiological unbalance of the elements.

Organic soils show progressively decreasing amounts of available manganese as their $\mathrm{pH}$ values increase. Beyond $\mathrm{pH} 6.0$ they may not have the ability to supply the plant requirements either from residual or applied manganese (8). If the $\mathrm{pH}$ is lowered, manganese solubility is increased and deficiency of this element prevented.

In a study of the effects of various soil treatments on improving an unproductive muck soil, Comin (2) obtained large increases in celery yields through sterilization of the soil.

Dawson (5) recommended that caution be observed in liming peat soils. At high $\mathrm{pH}$ values the application of lime usually caused a manganese deficiency on sensitive crops. He stated that the presence of free calcium carbonate whatever the source, might also cause manganese deficiency.

Townsend and Wedgworth (25) observed symptoms of yellowing and death of plants which were attributed to manganese deficiency. The trouble was associated with soils having a high content of marl. This deficiency was best prevented by adding both manganese and sulfur to the soil. Quastel, et al. (20) associated manganese deficiency with soils high in organic matter and lime status, and having a pH value between 6.5 and 8.0. He stated that applications of manganous sulfate to deficient soils are often ineffective because of the extremely rapid oxidation of the manganous ions and consequent fixation in an unavailable form, probably as manganese dioxide. The conclusion he reached is that the concentration of available manganese in the soil is a function of the kinetics of a number of reactions in what he terms the manganese cycle. Thus, to him, an increase in manganous ions can be accomplished as:

1. A direct result of reducing agents.

2. Using specific poisons.

3. Stimulation of manganese-reducing organisms relative to the oxidizing organisms.

In studies with sugarcane (28) upon areas where the soils were alkaline 
from burning, treatment with sulfur or sulfuric acid either with or without manganese has shown unusual benefits.

\section{EXPERIMENTATION}

ORGANIC SOILS IN PUERTO RICO

Organic soils in general have not been widely studied in Puerto Rico. Their chemical properties have not been studied yet, nor have their potentialities for use in agriculture received adequate study. Although there is a program for the reclamation of these lands the complexity of the problem per se is not only one of reclamation, but also of knowing the chemical properties of these soils and the problems likely to arise after their reclamation. That these soils can be rendered very productive is not to be doubted, but a knowledge of the intricacies of their management is of paramount importance. Every place in the world in which these soils have been used in agriculture, the users have had to deal with a wide variety of problems; to mention a few: Water table, weeds, toxicity, subsidence, and so forth, have presented a challenge to any one working with them.

In Puerto Rico there are more than 28,000 acres of organic soils, much of which can be used for crop production. Much of this land, if utilized properly, would greatly benefit the economy of the Island.

The distribution of organic soils in Puerto Rico (13) is as follows:

Soil series

Tiburones muck

Saladar muck

Saladar muck, shallow phase

Peat

Peat, shallow phase

Reparada

Ursula

Total

$\begin{array}{cc}\text { Soil group } & \text { Acres } \\ \text { Bog } & 6,848 \\ \text { do. } & 8,000 \\ \text { Half-bog } & 1,152 \\ \text { Bog } & 7,360 \\ \text { Half-bog } & 1,280 \\ \text { do. } & 2,560 \\ \text { do. } & 1,088 \\ & 28,180\end{array}$

SAMPLING AND DESCRIPTION OF SAMPLES

Twenty-five soil samples of the Caño Tiburones area were taken for analyses. The samples were taken at two depths, 0-8 and 8-24 inches. The typical vegetation growing in the area where the samples were taken consisted mostly of pasture, natural pasture, or pasture and brush, except in three places where sugarcane was growing.

The type of soils consisted mostly of Tiburones muck, Saladar muck, or peat. A description of these soils taken from the Soil Survey of Puerto Rico (22) follows:

\section{Tiburones Muck}

Areas of Tiburones muck, if not drained and cultivated, are covered with water most of the year. The most noticeable types of vegetation are ferns, sedges, grass, 
and cat-tails. When dry, drained, and cultivated, the surface soil to a depth of 10 inches is nearly black granular loose mealy more or less mineralized slightly acid friable muck, but when wet it is black plastic sticky muck. This layer is underlain by black stringy fibrous tule peat consisting of partly decomposed stems and fibers. It is slightly acid in reaction and salty. Here and there throughout this material, however, there is a band of somewhat blue or green plastic smooth clay about 6 or 8 inches thick, which is acid and slightly salty. Below the clay are other layers of tule peat.

\section{Saladar Muck}

Most areas of Saladar much are covered with water most of the time and support growing or cut-over mangrove forests. This type of muck consists of dark grayishbrown or black smooth salty strongly acid silty clay material and partly decomposed organic matter in which there is a mass of living and dead plant roots. In places there is a black slimy ooze covering the surface to a depth of 2 or 3 inches. At a depth of about 10 inches is brown smooth-textured organic matter containing layers of raw or partly decayed plant remains. In places the material from the surface down is black or very dark grayish-brown smooth fine-textured silt interspersed with plant remains in various stages of decomposition. Nearly all areas where this soil is present contain harmful quantities of salt brought in by the tide.

\section{Saladar Muck, Shallow Phase}

The shallow phase of Saladar muck represents a condition rather than a consistent development of a soil profile. It is always very wet, usually under water and generally contains considerable salt. In places it may be composed mostly of peat and muck, with some mineral soil, and in other places it may be mostly mineral soil, and in other places it may be mostly mineral soil with some 12 inches thick underlain by white acid sand.

\section{Peat}

Most of the peat areas are in mangrove swamps. Peat in general has a reddish brown coarsely fibrous surface material about 10 inches thick. In mangrove thickets it contains many somewhat yellow fine rootlets of mangroves, and in most places the top-most inch or two of the surface layer is black sticky tidal ooze. Below the surface layer is fine-fibered brown peat, which generally continues below a depth of four feet and rests on grayish-black or bluish-black plastic stickly clay containing many gray fine rootlets. Peat is acid in all layers and very salty unless drained.

\section{ANALYSES OF SAMPLES}

Samples were air-dried and ground in a mortar after which they were passed through a 2-mm. sieve. Analyses of the samples were done following the rapid microchemical soil tests as outlined by Peech and English (19). (See table 4 for the analytical results.)

\section{INTERPRETATION OF RESULTS}

Averages of the soil-test data for the three types of organic soils under study are presented in table 1 . The data indicate that Tiburones muck is better supplied with nutrients than either Saladar muck or peat. Soluble salts, iron, aluminum, and manganese are present in the least amounts in 
the peat-soil type; this seems to be favorable from the standpoint of crop production.

\section{PHOSPHORUS AND POTASSIUM}

As expected from a virgin peat soil results indicate a low level of fertility as far as available phosphorus and potassium are concerned. Phosphorus values are especially of such low level in the three soil types that application of phosphate fertilizer seems necessary.

The potassium level is higher in the Tiburones muck-soil type and lower in the peat soil type. The Saladar muck is of an intermediate level in respect to available potassium. The area sampled in general shows a need for an application of potassium fertilizer if the growing of crops is going to be undertaken successfully.

TABLE 1.-Average soil-test data for $\&$ types of organic soils from Puerto Ricol

\begin{tabular}{|c|c|c|c|c|c|c|c|c|c|}
\hline Soil type & $\begin{array}{l}\text { Depth } \\
\text { (inches) }\end{array}$ & $\mathbf{P}$ & $\underset{\mathbf{N}}{\mathrm{NO}}$ & $\underset{\mathrm{N}}{\mathrm{NH}_{8}}$ & $\mathbf{K}$ & Mn & Fe & Al & $\begin{array}{c}\text { Soluble } \\
\text { salts EC } \\
\times 10^{3}\end{array}$ \\
\hline Tiburones muck & $0-8$ & 4 & 52 & 102 & 387 & 90 & 278 & 79 & 11.75 \\
\hline Do. & $8-24$ & 4 & 31 & 102 & 414 & 94 & 259 & 81 & 17.65 \\
\hline Saladar muck & $0-8$ & 1 & 25 & 100 & 150 & 90 & 95 & 115 & 10.50 \\
\hline Do. & $8-24$ & 1 & 18 & 170 & 140 & 115 & 200 & 160 & 19.00 \\
\hline Peat & $0-8$ & 5 & 50 & 60 & 95 & 50 & 2 & 5 & 6.80 \\
\hline Do. & $8-24$ & 1 & 5 & 70 & 30 & 35 & 13 & 40 & 14.00 \\
\hline
\end{tabular}

${ }^{1}$ Results expressed in pounds of constituent per 2,000,000 pounds of soil.

\section{MANGANESE}

Manganese content is definitely lower in the peat-soil type than in either Tiburones muck or Saladar muck. No significant correlation was found between manganese values by soil test at 0-8 inches or 8-24 inches depth and $\mathrm{pH}$ values. Evidence of a probable manganese deficiency is seen, especially in spots where the $\mathrm{pH}$ of the soil is above 6.0 and the presence of free calcium carbonate has been detected.

\section{IRON AND ALUMINUM}

Iron values by soil test are higher in Tiburones muck. Saladar muck ranks intermediate in iron values and the peat-soil type has the lowest iron values.

Saladar muck has the highest content of aluminum by soil test, followed by Tiburones muck and peat.

Both iron and aluminum values by soil test show a highly significant negative correlation with soil $\mathrm{pH}$ values. In the case of iron the correlation coefficient was -0.716 and in the case of aluminum -0.920 .

In general, it can be said that the iron and aluminum values obtained 
indicate that toxicity of these elements will be a problem to deal with in the area studied. In the area where the $\mathrm{pH}$ was lower than 6.0 the iron and aluminum values obtained are often high enough to render the growth of crops unsatisfactory.

TABLE 2.-Conductivity values of soil samples expressed in millimhos/cm.

\begin{tabular}{|c|c|c|}
\hline Sample No. & $\mathrm{EC} \times 10^{2}$ (millimhos $/ \mathrm{cm}$.) at 0-8 in. & $\mathrm{EC} \times 10^{3}$ (millimhos $/ \mathrm{cm}$.) at 8-24 in. \\
\hline 1 & 10.5 & 7.6 \\
\hline 2 & 9.2 & 14.5 \\
\hline 3 & 7.6 & 8.5 \\
\hline 4 & 6.8 & 14.0 \\
\hline 7 & 3.5 & $\mathbf{5 . 5}$ \\
\hline 10 & 5.6 & 11.5 \\
\hline 15 & 10.0 & 17.0 \\
\hline 17 & 2.5 & 4.9 \\
\hline 18 & 2.8 & 5.8 \\
\hline 19 & 8.0 & 13.0 \\
\hline 21 & 7.2 & 14.0 \\
\hline 23 & 10.5 & 19.0 \\
\hline 24 & 12.5 & 19.0 \\
\hline 26 & 2.5 & 12.0 \\
\hline 27 & 11.5 & 18.0 \\
\hline 29 & 4.4 & 18.0 \\
\hline 32 & 13.0 & 20.0 \\
\hline 33 & 5.2 & 5.6 \\
\hline 37 & 22.0 & 38.0 \\
\hline 38 & 21.0 & 22.0 \\
\hline 41 & 15.5 & 33.0 \\
\hline 43 & 40.0 & 40.0 \\
\hline 45 & 27.0 & 40.0 \\
\hline 47 & 14.0 & 28.0 \\
\hline 50 & 4.8 & 10.0 \\
\hline
\end{tabular}

\section{Soluble Salts}

Because of the proximity of the area to the sea and for reasons described in discussing the origin and formation of Caño Tiburones, the author believes that a high salt content would be expected on certain spots of the area sampled.

A rough estimate of the salinity status of the area is presented. For convenience and also for reasons of comparison the soluble-salt content expressed in $\mathrm{K} \times 10^{5}$ units are converted to $\mathrm{EC} \times 10^{3}$ units. This unit is a practical conductivity unit for most soil-salinity work.

Table 2 shows the conductivity values obtained by analysis expressed in millimhos/centimeter.

Table 3 is an appraisal of the salinity problem in the area under study. 
The values of the conductivity scale as given by Richards et al. (21) have been multiplied by two because a more realistic view is given thus of the salinity problem under field conditions. Table 3 indicates that salinity would not be a problem if due precautions were taken in soil management practices.

The analysis of the samples procured for the soil tests is given in table 4 .

\section{SUMMARY AND CONCLUSIONS}

A general literature review on formation, subsidence, water table, and chemical properties of organic soils has been presented and discussed. Soil samples from a virgin peat soil of Puerto Rico were analyzed by rapid microchemical soil tests and, from them, the general fertility level of the

TABLE 3.-Appraisal of the salinity problem in the area under study

\begin{tabular}{|c|c|c|c|}
\hline $\begin{array}{l}\text { Scale of conductivity } \\
\text { (millimhos/cm. at } \\
\qquad 25^{\circ} \mathrm{C} \text {.) }\end{array}$ & Salinity effects & $\begin{array}{l}\text { Percentage of } \\
\text { samples from } \\
0-8 \text { in. }\end{array}$ & $\begin{array}{l}\text { Percentage of } \\
\text { samples from } \\
8-24 \text { in. }\end{array}$ \\
\hline 0 & Salinity effects mostly negligible & 12 & 0 \\
\hline 4 & $\begin{array}{l}\text { Yields of very sensitive crops may be } \\
\text { restricted }\end{array}$ & 32 & 20 \\
\hline 8 & Yields of many crops restricted & 40 & 32 \\
\hline 16 & $\begin{array}{l}\text { Only tolerant crops yield satisfac- } \\
\text { torily }\end{array}$ & 12 & 32 \\
\hline 32 & $\begin{array}{l}\text { Only a few very tolerant crops yield } \\
\text { satisfactorily }\end{array}$ & 4 & 16 \\
\hline
\end{tabular}

area sampled was evaluated. The relation of the different soil types to the soil-test data has been presented.

From the preceding investigation the following conclusions were drawn:

1. The virgin peat soils from Puerto Rico are low in phosphorus and potassium.

2. No significant correlation was found between manganese values by soil test and soil $\mathrm{pH}$ values.

3. A probable manganese deficiency is seen in spots where the $\mathrm{pH}$ of the soils is above 6.0 , and the presence of free calcium carbonate has been detected.

4. A highly significant negative correlation was found for iron values by soil test and soil $\mathrm{pH}$ values.

5. A highly significant negative correlation was found for aluminum values by soil test and soil $\mathrm{pH}$ values.

6. In areas where the $\mathrm{pH}$ was lower than 6.0 the iron and aluminum values obtained are often high enough to render growth of crops unsatisfactory. 
TABLE 4.-Analysis of samples-results of soil tests

\begin{tabular}{|c|c|c|c|c|c|c|c|c|c|c|c|}
\hline \multirow[b]{2}{*}{$\begin{array}{l}\text { Sam- } \\
\text { ple } \\
\text { No. }\end{array}$} & \multirow[b]{2}{*}{$\begin{array}{l}\text { Depth of of } \\
\text { sample }\end{array}$} & \multirow[b]{2}{*}{ pH } & \multicolumn{9}{|c|}{ Pounds per acre $\left(2 \times 10^{\circ} \mathrm{lb}\right.$. of soil $)$} \\
\hline & & & $\mathbf{P}$ & $\underset{\mathrm{N}}{\mathrm{NO}_{2}}$ & $\underset{\mathrm{N}}{\mathrm{NH}_{3}}$ & $\mathbf{K}$ & $\mathbf{M n}$ & Fe & Al & $\mathrm{CaCO}_{z}$ & $\begin{array}{l}\text { Soluble } \\
\text { salts K } \\
\times 10^{5}\end{array}$ \\
\hline \multirow[t]{2}{*}{1} & $0-8^{\prime \prime}$ & 5.75 & 2.5 & 60 & 85 & 270 & 160 & 190 & 120 & + & 1,050 \\
\hline & $8-24^{\prime \prime}$ & 5.80 & 2 & 10 & 110 & 320 & 75 & 100 & 55 & $+t+$ & 760 \\
\hline \multirow[t]{2}{*}{2} & $0-8^{\prime \prime}$ & 7.55 & 6 & 40 & 100 & 160 & 300 & 4 & 5 & $+t+t$ & 920 \\
\hline & $8-24^{\prime \prime}$ & 7.35 & 4 & 10 & 100 & 150 & 400 & 35 & 5 & $+t+t$ & 1,450 \\
\hline \multirow[t]{2}{*}{3} & $0-8^{\prime \prime}$ & 5.90 & 1 & 10 & 75 & 170 & 100 & 80 & 95 & +++ & 760 \\
\hline & $8-24^{\prime \prime}$ & 5.75 & 1 & $\mathbf{5}$ & 50 & 115 & 40 & 65 & 90 & - & 850 \\
\hline \multirow[t]{2}{*}{4} & $0-8^{\prime \prime}$ & 7.25 & 5 & 50 & 60 & 95 & 50 & 2 & 5 & $+t+t$ & 680 \\
\hline & $8-24^{\prime \prime}$ & 5.85 & 1 & $\mathbf{5}$ & 70 & 30 & 35 & 13 & 40 & - & 1,400 \\
\hline \multirow[t]{2}{*}{7} & $0-8^{\prime \prime}$ & 7.55 & 8 & 30 & 75 & 130 & 90 & 5 & $\mathbf{5}$ & $+t+t$ & 350 \\
\hline & $8-24^{\prime \prime}$ & 6.55 & 5 & 5 & 60 & 100 & 5 & 1 & 10 & $+t$ & 550 \\
\hline \multirow[t]{2}{*}{10} & $0-8^{\prime \prime}$ & 6.80 & 2 & 50 & 60 & 170 & 50 & 7 & 10 & $t+t+$ & 560 \\
\hline & $8-24^{\prime \prime}$ & 5.25 & 1 & $\mathbf{5}$ & 60 & 65 & $\mathbf{5}$ & 30 & 70 & - & 1,150 \\
\hline \multirow[t]{2}{*}{15} & $0-8^{\prime \prime}$ & 5.35 & 1 & 10 & 65 & 85 & 45 & 130 & 95 & + & 1,000 \\
\hline & $8-24^{\prime \prime}$ & 5.40 & 1 & $\mathbf{5}$ & 75 & 95 & 45 & 40 & 50 & - & 1,700 \\
\hline \multirow[t]{2}{*}{17} & $0-8^{\prime \prime}$ & 7.25 & 4 & 85 & 60 & 230 & 10 & 2 & $\mathbf{5}$ & $+t+t$ & 250 \\
\hline & $8-24^{\prime \prime}$ & 6.20 & 1 & $\mathbf{5}$ & 75 & 55 & 8 & 3 & 10 & + & 490 \\
\hline \multirow[t]{2}{*}{18} & $0-8^{\prime \prime}$ & 7.40 & 20 & 80 & 50 & 85 & 5 & 1 & $\mathbf{5}$ & +++ & 280 \\
\hline & $8-24^{\prime \prime}$ & 7.15 & 16 & 45 & 50 & 65 & 5 & 1 & 5 & $++t$ & 580 \\
\hline \multirow[t]{2}{*}{19} & $0-8^{\prime \prime}$ & 7.35 & 3 & 85 & 75 & 210 & 70 & 1 & 5 & $+t+t$ & 800 \\
\hline & $8-24^{\prime \prime}$ & 7.00 & 1 & 20 & 60 & 50 & 110 & 1 & 5 & - & 1,300 \\
\hline \multirow[t]{2}{*}{21} & $0-8^{\prime \prime}$ & 4.85 & 1 & 60 & 105 & 250 & 5 & 80 & 100 & - & 720 \\
\hline & $8-24^{\prime \prime}$ & 4.25 & 1 & 20 & 150 & 150 & 8 & 220 & 190 & - & 1,400 \\
\hline \multirow[t]{2}{*}{23} & $0-8^{\prime \prime}$ & 5.25 & 1 & 25 & 100 & 150 & 90 & 95 & 115 & - & 1,050 \\
\hline & $8-24^{\prime \prime}$ & 4.35 & 1 & 18 & 170 & 140 & 115 & 200 & 160 & - & 1,900 \\
\hline \multirow[t]{2}{*}{24} & $0-8^{\prime \prime}$ & 5.15 & 2 & 45 & 110 & 440 & 120 & 55 & 80 & - & 1,250 \\
\hline & $8-24^{\prime \prime}$ & 3.75 & 1 & 50 & 225 & 190 & 210 & 800 & 165 & - & 1,900 \\
\hline 26 & $0-8^{\prime \prime}$ & 6.05 & 2 & 10 & 65 & 170 & 55 & 7 & 45 & + & 1,250 \\
\hline & $8-24^{\prime \prime}$ & 5.60 & 1 & $\mathbf{5}$ & 75 & 130 & 55 & 20 & 80 & - & 1,200 \\
\hline 27 & $0-8^{\prime \prime}$ & 6.95 & 7 & 200 & 90 & 740 & 50 & 3 & $\mathbf{5}$ & $+t+t$ & 1,150 \\
\hline & $8-24^{\prime \prime}$ & 6.95 & 3 & 250 & 50 & 360 & 65 & 18 & 5 & $+t+t$ & 1,800 \\
\hline 29 & $0-8^{\prime \prime}$ & 6.45 & 1 & $\mathbf{5}$ & 55 & 220 & 85 & 1 & 35 & ++ & 440 \\
\hline & $8-24^{\prime \prime}$ & 6.05 & 1 & 8 & 75 & 145 & 60 & 7 & 45 & - & 1,800 \\
\hline 32 & $0-8^{\prime \prime}$ & 7.35 & 10 & 20 & 100 & 120 & 220 & 3 & $\mathbf{5}$ & $t+t+$ & 1,300 \\
\hline & $8-24^{\prime \prime}$ & 6.35 & 20 & 5 & 55 & 145 & 30 & 1 & 5 & - & 2,000 \\
\hline 33 & $0-8^{\prime \prime}$ & 7.65 & 6 & 30 & 95 & 95 & 260 & 40 & 5 & ++++ & 520 \\
\hline & $8-24^{\prime \prime}$ & 7.75 & 3 & 35 & 110 & 65 & 350 & 85 & 5 & $+t+t$ & 560 \\
\hline 37 & $0-8^{\prime \prime}$ & 4.15 & 2 & 25 & 115 & 530 & 130 & 250 & 120 & - & 2,200 \\
\hline & $8-24^{\prime \prime}$ & 3.35 & 3 & 45 & 220 & 740 & 110 & 1,000 & 200 & - & 3,800 \\
\hline 38 & $0-8^{\prime \prime}$ & 3.85 & 1 & 20 & 80 & 525 & 85 & 240 & 110 & - & 2,100 \\
\hline & $8-24^{\prime \prime}$ & 6.25 & 9 & 5 & 100 & 415 & 200 & 45 & 35 & $+t+t$ & 2,200 \\
\hline 41 & $0-8^{\prime \prime}$ & 4.45 & 3 & 70 & 80 & 650 & 40 & 1,100 & 255 & - & 1,550 \\
\hline & $8-24^{\prime \prime}$ & 4.10 & 2 & 15 & 100 & 680 & 90 & 200 & 175 & - & 3,300 \\
\hline 43 & $0-8^{\prime \prime}$ & 3.80 & 4 & 50 & 270 & 1,680 & $\mathbf{5}$ & 1,000 & 190 & - & 4,000 \\
\hline & $8-24^{\prime \prime}$ & 4.90 & 4 & 5 & 60 & 2,945 & 5 & 2 & 35 & - & 4,000 \\
\hline 45 & $0-8^{\prime \prime}$ & 3.50 & 3 & 90 & 350 & 755 & 40 & 1,200 & 190 & - & 2,700 \\
\hline & $8-24^{\prime \prime}$ & 4.35 & 1 & $\mathbf{5}$ & 240 & 1,470 & 25 & 85 & 115 & - & 4,000 \\
\hline 47 & $0-8^{\prime \prime}$ & 3.45 & 3 & 65 & 100 & 870 & 30 & 1,100 & 135 & - & 1,400 \\
\hline & $8-24^{\prime \prime}$ & 2.95 & 2.5 & 65 & 100 & 870 & 110 & 1,100 & 225 & - & 2,800 \\
\hline 50 & $0-8^{\prime \prime}$ & 4.40 & 3 & 50 & 75 & 345 & 120 & 900 & 200 & - & 480 \\
\hline & $8-24^{\prime \prime}$ & 3.30 & 4 & 85 & 140 & 195 & 150 & 2,100 & 275 & - & 1,000 \\
\hline
\end{tabular}


7. Salinity is not a problem in the area studied if correct soil-management practices are used.

\section{RESUMEN Y CONCLUSIONES}

Se ha presentado un repaso de la literatura en relación a la formación, descenso, nivel freático y propiedades químicas de los suelos orgánicos.

Fué evaluado el nivel de fertilidad de un suelo turboso virgen de Puerto Rico. Como resultado de esta investigación se ha llegado a las siguientes conclusiones:

1. Los suelos turbosos vírgenes de Puerto Rico son bajos en fósforo y potasio.

2. No se encontró una correlación significativa entre los valores de manganeso obtenidos por análisis del suelo y la acidez de los suelos turbosos.

3. Una probable deficiencia de manganeso se prevee en los sitios donde hay carbonato de cal libre y el $\mathrm{pH}$ del suelo es sobre 6.0.

4. Una alta y significativa correlación negativa fué encontrada entre los valores de hierro obtenidos por análisis del suelo y la acidez de los suelos turbosos.

5. Una alta y significativa correlación negativa fué encontrada entre los valores de aluminio obtenidos por análisis del suelo y la acidez de los suelos turbosos.

6. En los sitios donde los valores de hierro y aluminio obtenidos son altos y donde el pH del suelo es menor de 6.0, el crecimiento de las cosechas, probablemente, estará limitado por estos factores.

7. La salinidad no es un problema en el área estudiada, si se usan las prácticas correctas para el manejo de los suelos.

\section{LITERATURE CITED}

1. Allaway, W. H., Availability of replaceable calcium from different types of colloids as affected by degree of calcium saturation, Soil Sci. 59 207-17, 1945.

2. Comin, $\mathrm{D}$., The effect of various soil treatments on improving an unproductive muck soil, Soil Sci. Soc. Amer. Proc. 10 279-81, 1945.

3. Dachnowski-Stokes, A. P., Peat deposits in U. S. A., Handbuch der Moorkunde Bond 7 1-140, 1933.

4. Dawson, J. E., Memorandum to Committee on Organic Soils, Classification of Peat Soils, March 1954.

5. - Organic Soils, Advances in Agronomy 8, 1956.

6. Ellis, N. K., and Morris, R., Preliminary observations on the relation of yields of crops grown on organic soil with controlled water table and the area of aeration in the soil and subsidence of the soil, Soil Sci. Soc. Amer. Proc. 10 282-3, 1945.

7. Forsee, Jr., W. T., Erwin, T. C., and Kretschmer, Jr., A. E., Copper Oxide as a Source of Fertilizer Copper for Plants Growing on Everglades Organic Soils, Univ. Fla. Agr. Exp. Sta. Bul. 552, 1954.

8. - Conditions affecting the availability of residual and applied manganese 
in the organic soils of the Florida Everglades, Soil Sci. Soc. Amer. Proc. 18 475-8, 1954.

9. Harmer, P. M., Studies on the effect of copper sulfate applied to organic soil on the yield and quality of several crops, Soil Sci. Soc. Amer. Proc. 10 284-94, 1945.

10. Jones, L. A., Soils, Geology, and Water Control in the Everglades Region, Univ. Fla. Agr. Exp. Sta. Bul. 442, 1948.

11. Jongedyk, H. A., Hickok, B. B., and Mayer, I. D., Changes in drainage properties of a muck soil as a result of drainage practices, Soil Sci. Soc. Amer. Proc. 18 72-6, 1954 .

12. Lucas, R. E., The effect of the addition of sulfates of copper, zinc, and manganese on the absorption of these elements by plants grown on organic soils, Soil Sci. Soc. Amer. Proc. 10 269-74, 1945.

13. Lugo-López, M. A., and Bonnet, J. A., Utilization of organic soils in Puerto Rico, J. Agr. Univ. P. R. 35 (2) 57-65, 1951.

14. Neller, J. R., Oxidation loss of Lowmoor peat in fields with different water tables, Soil Sci. 58 195-204, 1944.

15. - Reclamation and soil conservation problems of the Florida Everglades: AThe physical phase, Soil Sci. Soc. Fla. Proc. 4 9-10, 1942.

16. - Factors Affecting Composition of Everglades Grasses and Legumes, with Special Reference to Proteins and Minerals, Univ. Fla. Agr. Exp. Sta. Bul. 403, 1944.

17. - Influence of cropping, rainfall, and water table on nitrates in Everglades peat, Soil Sci. 67 275-80, 1944.

18. Nygard, J. J., Identification of lime deficient peat soils, Soil Sci. Soc. Amer. Proc. 18 188-92, 1954.

19. Peech, M., and English, L., Rapid microchemical soil tests, Soil Sci. 57 167-95, 1944.

20. Quastel, J. H., Hewitt, E. J., and Nicholas, D. J. D., The control of manganese deficiency in soils, $J$. Agr. Sci. 38 315-22, 1948.

21. Richards, L. A., and U. S. Salinity Laboratory Staff, Diagnosis and Improvement of Saline and Alkali Soils, Agr. Handbook 60, USDA, 1954.

22. Roberts, R. C., and Party, Soil Survey of P. R., USDA Series 1936, No. 8 354-56, 1942.

23. Stacker, E. V., Sulfur-zinc relationships in some New York peat soils, Soil Sci. Soc. Amer. Proc. 8 345, 1944.

24. Stoutmaire, R., Drainage and Water Control in Florida, Fla. Dept. Agr. Bul. 51, 1931.

25. Townsend, G. R., and Wedgworth, H. H., A Manganese Deficiency Affecting Beans, Univ. Fla. Agr. Exp. Sta. Bul. 300, 1936.

26. University of Fla. Agr. Exp. Sta. Annual Report, June 30, 1935.

27. - Annual Report, June 20, 1940.

28. - Anmual Report, June 30, 1930.

29. Vaino, A., Peat bogs of southeastern Canada, Handbuch der Moorkunde Bond 7 141-223, 1933.

30. Waksman, S. A., and Stevens, K. R., Contribution to the chemical composition of peat: I. Chemical nature of organic complexes in peat and methods of analysis, Soil Sci. 26 113-37, 1928.

31. - Contribution to the chemical composition of Peat: II. Chemical composition of various peat profiles, Soil Sci. 26 239-51, 1928. 